\title{
Downregulated suppression to obtain upregulated reprogramming
}

\author{
Ari A. Mennander, MD, PhD
}

From Tampere University Heart Hospital and Tampere University, Tampere, Finland.

Disclosures: Author has nothing to disclose with regard to commercial support.

Received for publication March 20, 2018; accepted for publication March 22, 2018; available ahead of print April $18,2018$.

Address for reprints: Ari A. Mennander, MD, PhD, Tampere University Heart Hospital, SDSKIR, PL 2000, Tampere, Finland (E-mail: ari.mennander@sydansairaala.fi).

J Thorac Cardiovasc Surg 2018;156:566-7

$0022-5223 / \$ 36.00$

Copyright (c) 2018 by The American Association for Thoracic Surgery

https://doi.org/10.1016/j.jtcvs.2018.03.083

Advanced heart failure is dramatically increasing worldwide. It is characterized by the loss of viable cardiomyocytes, leading to cardiac fibrosis and scar formation. Treatment option includes complex, but often insufficient, medication; implantation of mechanical circulatory support; and even cardiac transplantation. ${ }^{1}$ In short, much clinical and research effort is consumed in helping these patients. Implantation of novel cardiomyocytes, such as those procured from cardiac stem cells or induced pluripotent stem cells, has been conceptualized to add to successful myocardial regeneration. Sadly, despite initial expectations, results from experimental setups are not applicable in humans. Human stem cells are resistant to reprogramming, which is fundamental for the implantation process and subsequent regeneration of myocardium.

Meanwhile, research on tumors and embryonic stem cells has previously revealed that tumor suppressor genes, such as p53 and p63, participate in the regulation of tissue growth $^{2}$ and are essential for cardiogenesis. ${ }^{3}$ A controlled downregulation of p63 may safely induce cardiac tissue growth without compromising cell differentiation and regeneration. ${ }^{4}$ In their article in this issue of the Journal, Patel and colleagues ${ }^{5}$ hypothesized that downregulation of p63 may enhance tissue growth and activate stem cell reprogramming into cardiomyocytelike cells. The aim of the experimental study was to downregulate p63 with several different cell lines, such as murine embryonic fibroblasts, adult murine cardiac fibroblasts, and human cardiac fibroblasts. For control, wild-type cells were used. The methods included cell culture with vectors enhancing the downregulation of p63. The cells were carefully characterized for viability by means of flow cytometry, evaluation of gene expressions, immunofluorescence studies, measurement of cell contractility, and calcium ion concentration determination. Special attention was given to studying cell proliferation to reveal any induction of malignancy.

The results were outstanding. Flow cytometry showed increased cardiac-specific marker troponin $\mathrm{T}$ in $\mathrm{p63-}$ downregulated cells, especially after treatment with

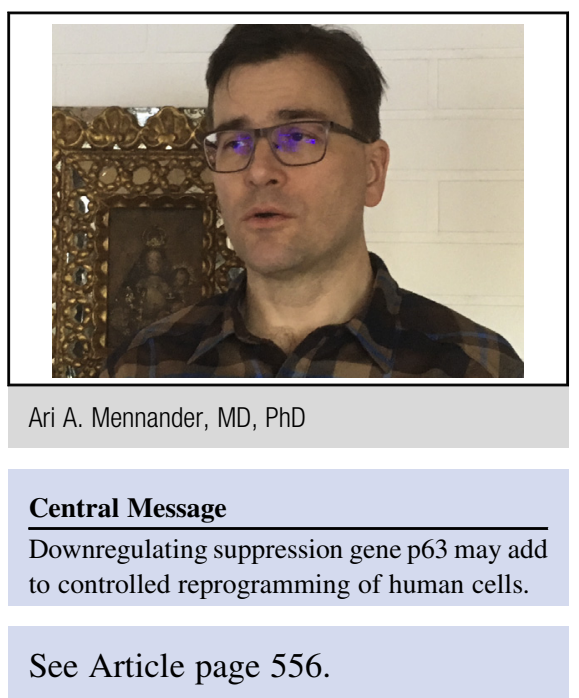

myocardin, a well-known cardiac transcription factor. In the vicinity of neonatal cardiomyocytes, transient changes in calcium ion concentration and electrically-stimulated contractions were discovered in these p63-downregulated fibroblasts. suggesting viability. Importantly, the manipulation of p63 did not enhance oncogenesis but rather was specifically translated to serve cardiac regeneration. Instead of activating yet another mixture of potential catalysts in the attempt to reprogram cardiac stem cells, Patel and colleagues ${ }^{5}$ showed that downregulation of an inhibitor of active reprogramming would allow the stem cells to regenerate. This raises the exciting question of whether adult somatic cells could be reengineered genetically into functionally powerful induced pluripotent stem cells by downregulating p63 and then be activated into novel cardiomyocytes.

Sane skepticism must still be retained. Human cells are heterogeneous and unpredictable in their response to genetic manipulation. ${ }^{2}$ Many a stubborn cell may surrender if rendered vulnerable in vitro by suppression of early inactivation. The adequate timing, stability, and extent of downregulating p63 while interfering with cell development all need to be addressed. ${ }^{2}$ This requires repeated translational research to assure the clinical community of the efficacy and safety of this approach. ${ }^{2,5}$ We would need to certify whether the transdifferentiation of the fibroblasts into induced cardiomyocytes results in regeneration into fresh and viable myocardium. 


\section{References}

1. Yancy CW, Jessup M, Bozkurt B, Butler J, Casey DE Jr, Drazner MH, et al. 2013 ACCF/AHA guideline for the management of heart failure: executive summary: a report of the American College of Cardiology Foundation/American Heart Association task force on practice guidelines. Circulation. 2013;128:1810-52.

2. Rasmussen MA, Holst B, Tümer Z, Johnsen MG, Zhou S, Stummann TC, et al. Transient p53 suppression increases reprogramming of human fibroblasts without affecting apoptosis and DNA damage. Stem Cell Reports. 2014;9:404-13.
3. Rouleau M, Medawar A, Hamon L, Shivtiel S, Wolchinsky Z, Zhou H, et al TAp63 is important for cardiac differentiation of embryonic stem cells and heart development. Stem Cells. 2011;29:1672-83.

4. Iannolo G, Sciuto MR, Raffa GM, Pilato M, Conaldi PG. MiR34 inhibition induces human heart progenitor proliferation. Cell Death Dis. 2018;9:368-77.

5. Patel V, Singh VP, Pinnamaneni JP, Sanagasetti D, Olive J, Mathison M, et al p63 silencing Induces reprogramming of cardiac fibroblasts into cardiomyocytelike cells. J Thorac Cardiovasc Surg. 2018;156:556-65.e1. 